\title{
TEACHER'S STRATEGY IN MAINTAINING THE FLOW OF STUDENTS' ENGLISH INTERACTION IN SPEAKING CLASS
}

\section{Strategy Guru dalam Mempertahankan Arus Interaksi Bahasa Inggris Siswa Pada Kelas Berbicara}

\section{Herlina Daddi}

English Education Department, Faculty of Teacher Training and Education

Muhammadiyah University of Makassar

daddiherlina@yahoo.co.id

\begin{abstract}
This qualitative mini-research aimed to reveal the strategy used by a teacher in speaking class. The researcher observed a teacher in one of private university in Makassar for three meetings in a speaking class. In addition, the researcher did an interview to the teacher and her fifteen students who attended in her class. The finding implied that the teacher employed communicative approach by giving pair and group work activities. She also applied a rule Don't Speak in Bahasa (no one is allowed to speak in Indonesia including herself) with reward and punishment. Moreover, the interview indicated that the teacher's strategy in speaking class motivated the students to speak fully in English and built up their confidence.
\end{abstract}

Keywords: speaking, strategy, rule.

The mastery of speaking skill in English is a priority for many foreign language learners. Learners consequently often evaluate their success in language learning as well as the effectiveness of their English course on the basis of how well they feel they have improved in their spoken language proficiency. They usually feel insecure about their level of English and they face problems communicating as well as expressing themselves in the target language because of lack of vocabulary or lack of confidence. As a result, they often speak in their native language or rather remain silent as they are in fear of making mistakes and do not show active participation in speaking lessons. Therefore, it is a demanding task for language teacher to provide sufficient inputs for students to be competent speakers of English. Moreover, in speaking class, the students should be exposed to the target language in varying activities. The components of English speaking skill should also be given and practiced in terms of fluency, accuracy and comprehensibility.

Dealing with the endeavor to facilitate students to have abilities to carry out conversation on the target language, teachers and textbooks make use of a variety of approaches, ranging from direct approaches focusing on specific features of oral interaction (e.g. turn-taking, topic management, questioning strategies) to indirect 
approaches which create conditions for oral interaction through group work, task work and other strategies (Richards, 1990).

Furthermore, in promoting as much English use as possible, a number of researches conducted. Ibadurrahman (2011) did a mini classroom research which aimed to find out whether or not the strategy of creating behavior norms works on reducing student's mother tongue in a senior high school. There were two meetings in which the research was conducted. At first, meeting where the idea of behavior norms was not introduced, students kept using their mother tongue as if they hadn't known they were in English class. This condition did not improve although the teacher attempted to reinforce students to use English. Students were blissfully unaware of the importance of speaking English, students had no idea that using mother tongue would not only hinder English learning, of all 25 students who attended the class, 16 of them used Indonesian (64\%) in long phrase.

Conversely, in the second meeting, the researcher noticed some improvement on the use of target language. Norms of behavior were explained and negotiated. It was at this stage that students began realizing the importance using English and stop using the native language. With the norms being conducted, there would now be consequences to those who step outside of those norms-that is they would have to tell their personal story to everyone in the class which will also be recorded and published on Facebook for the whole world to see. Students tried their best to speak in full English although was produced in broken English. Among 25 who were present that day, only 8 students used Indonesian phrases, some were only a word as compared to the first meeting.

Besides, Abassy (2011) conducted a survey to what kind of teaching strategies are applied by English language teachers for the development of linguistic abilities of ESL learners at intermediate level in Pakistan. The study focuses on the related analysis of English language teaching strategies applied by both Public sector and Private sector at intermediate level at District Jacobabad, Sindh, Pakistan. The study applies both quantitative and qualitative methods for data analysis. Participating subjects were 40 English language teachers of intermediate level of Public sector and Private sector schools and colleges. The ELT teachers were interviewed in details coupled with data via questionnaires. The evidence from 
the data manifests that the ELT teachers of public sector are more inclined to apply the teaching strategies of GTM (Grammar Translation Method) while Private sector teachers are interested in Communicative Teaching Approach Strategies. Furthermore, the study suggests that there is a great need to train and motivate Public sector teachers through workshops for applying Communicative Teaching Approach Strategies in their ESL context in order to make their ESL learners communicatively competent.

The problems and the two previous researches to be the basis for this research to know what a teacher does to keep the students interact in English during the class.

The research question was formulated as follows: "what are strategies applied in maintaining of students' English interaction?" The objective of this research was to find out and describe the strategies of English teacher in maintaining the students' English interaction.

\section{THE CONCEPT OF SPEAKING}

Finochiaro in Sukrianto (2005: 22) claimed that speaking is a real language, which means that the capability to communicate in a language can be shown through the skill of speaking. The skill of speaking refers to the students' ability to express mind or feeling orally. One function of speaking is to communicate ideas in situation where the other person is listening to words and can be in front of the speaker, looking at the gesture and facial expression. Furthermore, speaking is an interactive process of constructing meaning that involves producing and receiving and processing information (Burn and Joyce, 1997: 63). Its form and meaning are dependent on the context in which it occurs, including the participants themselves, their collective experiences, the physical environment, and the purposes for speaking. In other words, we can say that speaking is the skill or capability to deliver messages directly.

\section{Principle and Approaches for Teaching Speaking}

Brown (2007: 331-332) on his book 'Teaching by Principles' wrote principles for teaching speaking skill, they are;

1. Focus on both fluency and accuracy depending on your objective.

2. Provide intrinsically motivating techniques. 
Try at all times to appeal to students' ultimate goals and interests, to their need for knowledge, for status, for achieving competence and autonomy, and for being all that they can be". Helping them to see how the activity will benefit for them. Often students don't know why we ask them to do certain things; it usually pays to tell them.

3. Encourage the use of authentic language in meaningful contexts.

4. Provide appropriate feedback and correction.

In most EFL situations, students are totally dependent on the teacher for useful linguistic feedback. In ESL situations, they may get such feedback "out there" beyond the classroom, but even then you are in a position to be a great benefit. It is important that you take advantage of your knowledge of English to inject the kinds of correction feedback that are appropriate for the moment.

5. Capitalize on the natural link between speaking and listening.

Many interactive techniques that involve speaking will also of course include listening. Don't lose out on opportunities to integrate these two skills. As you are perhaps focusing on speaking goals, listening goals may naturally coincide, and the two skills can reinforce each other. Skills in producing language are often initiated through comprehension.

6. Give students opportunities to initiate oral communication

A good deal of typical classroom interaction is characterized by teacher initiation of language. We ask questions, give directions, and provide information, and students have been conditioned only to "speak when spoken to". Part of oral communication competence is the ability to initiate conversations, to nominate topics, task questions, to control conversations, and to change the subject. As you design and use speaking techniques, ask yourself if you have allowed students to initiate language.

7. Encourage the development of speaking strategies.

The students need encouraging to develop their own personal strategies for accomplishing oral communicative purposes, such strategies as

- Asking for clarification (What?)

- Asking someone to repeat something (Huh? Excuse me?)

- Using fillers (Uh, I mean, Well) in order to gain time to process 
- Using conversation maintenance cues (Uh-huh, Right, Yeah, Okay, Hm)

- Using paraphrases for structures one can't produce

- Appealing for assistance from the interlocutor (to get a word or phrase, for example)

- Using formulaic expression (at the survival stage) (how much does cost? How do you get to the ?)

- Using mime and nonverbal expression to convey meaning

Moreover, an approach as a set of assumptions dealing with the nature of the language, learning and teaching (Antony's view in Brown 2007: 14) will be reflected to teaching method. According to Pollard (2008), there are eight approaches in term of method in teaching English, they are:

1. Grammar translation method

The method consists of studying written texts, translating them into the students' own language and carrying out a study of grammar.

2. Audio-lingual method

It involves providing a stimulus to which students respond; if the response is correct, the students are praised in order to reinforce the correct use of language and ultimately to reinforce learning. Language is presented in a very controlled way; i.e. one language point at a time is studied and worked on. Grammar explanations are kept to a minimum and progress is made through repetition.

3. Communicative approach

This approach developed out of a need to have students communicating for real. It is based on the theory that children acquire language rules by using language rather than through the study of grammar. It involves creating situations where the students have a genuine need to say something, just as children do.

4. PPP (Presentation, Practice, and Production)

Presentation might be similar to the audio-lingual approach through the use of pictures and focused learning. It can also be achieved through explanation and demonstration. Practice refers to controlled practice; it involves students using the target language in a controlled way. This might involve drills, controlled written and speaking activities, and repetition. Production refers to freer practice; students use the target language in sentences of their own. 


\section{Task-based learning}

In a task-based lesson, the teacher sets a task for students to do that involves the use of language not yet studied in class or language studied previously that the teacher wishes to revise. The language point chosen is known as target language.

\section{ESA (Engage-Study-Activate)}

Engage involves getting the students' attention or interest, getting them involved. The idea is that if students are involved or engaged, they are more open to the learning process.

\section{Strategies for Developing Speaking Skills}

Students often think that the ability to speak a language is the product of language learning, but speaking is also a crucial part of the language learning process. Effective instructors teach students speaking strategies such as follows;

1. Using minimal responses

Language learners who lack confidence in their ability to participate successfully in oral interaction often listen in silence while others do the talking. One way to encourage such learners to begin to participate is to help them build up a stock of minimal responses that they can use in different types of exchanges. Such responses can be especially useful for beginners.

Minimal responses are predictable, often idiomatic phrases that conversation participants use to indicate understanding, agreement, doubt, and other responses to what another speaker is saying. Having a stock of such responses enables a learner to focus on what the other participant is saying, without having to simultaneously plan a response.

\section{Recognizing scripts}

Some communication situations are associated with a predictable set of spoken exchanges -- a script. Greetings, apologies, compliments, invitations, and other functions that are influenced by social and cultural norms often follow patterns or scripts. So do the transactional exchanges involved in activities such as obtaining information and making a purchase. In these scripts, the relationship between a speaker's turn and the one that follows it can often be anticipated. 
Instructors can help students develop speaking ability by making them aware of the scripts for different situations so that they can predict what they will hear and what they will need to say in response. Through interactive activities, instructors can give students practice in managing and varying the language that different scripts contain.

3. Using language to talk about language

Language learners are often too embarrassed or shy to say anything when they do not understand another speaker or when they realize that a conversation partner has not understood them. Instructors can help students overcome this reticence by assuring them that misunderstanding and the need for clarification can occur in any type of interaction, whatever the participants' language skill levels. Instructors can also give students strategies and phrases to use for clarification and comprehension check.

\section{Types of speaking activity}

Pollard (2008: 34) presented eight types of speaking activities, they are: information gap, discussions: reaching a consensus, discussions involving opinion, debates, spontaneous conversations, role play, problem solving and topic prompts.

\section{Characteristics of a Successful Speaking Activity}

Ur (1996: 120) proposes four characteristics of successful speaking activity, namely: 1) learners talk a lot that is as much as possible of the period of time allotted to the activity is in fact occupied by learner talk, 2) participation is even that is classroom discussion is not dominated by a minority of talkative participations: all get a chance to speak, and contributions are fairly evenly distributed, 3) motivation is high in which learners are eager to speak because they are interested in the topic and have something new to say about it, or because they want to contributed to achieving a task objective and 4) language is of an acceptable level in which learners express themselves in utterances that are relevant, easily comprehensible to each other, and of an acceptable level of language accuracy. 


\section{RESEARCH METHODOLOGY}

\section{Research method}

In this research, the researcher used qualitative study by applying grounded theory. Qualitative research is the collection, analysis, and interpretation of comprehensive narrative and visual (nonnumeric) data in order to gain insights into a particular phenomenon of interest (Gay et al, 2006: 399).

\section{Participants}

The participant of the current research was a female teacher with teaching certificate from faculty of teacher training and education in private university in Makassar. She has experienced in teaching English for 7 years. This observation conducted in her speaking 1 class with 40 students. Her 40 students also participated in this mini research.

\section{Data collection}

Data collection included direct observation and interview. To observe the classroom activities, the researcher made a field note from the class began to closed and used video recorder to explore classroom interaction. The interview was aimed to obtain students' feedback toward the teacher's strategy in speaking class. In doing this interview, the researcher did snowball technique.

\section{Data Analysis}

In analyzing the data, the researcher adapted a procedure of grounded theory of data analysis that was 'open coding' by Strauss and Cobin (1990) in Atmowardoyo (2010: 44-46). It covered observation sheet, naming phenomena, conceptual label, finding and naming category, and making general description.

\section{FINDING AND DISCUSSION}

\section{Finding}

The result of field note indicated some phenomena, they are:

1. In conducting speaking class the teacher used English only, no word presented in Indonesia (as their native language). This rule was negotiated with the students in the first meeting and for whoever in the class breaking the rule had to pay fine.

2. Putting the students in pair 
At the time when the observation conducted, the teacher used one type of speaking activities that was 'information gap'. Students work in pair; student A has a simple picture which (s) he doesn't show to B; students B has a piece of blank picture. Students A describe the picture; students B listens and draws it. Finally, students compared what B drew with original.

3. Controlling the activity

To control pair or group activity, the teacher went around the classroom and reminded students to interact in English (she said 'Don't speak in Bahasa'). By walking around was the way to discourage students speaking in their native language and monitoring their participation and also giving support and help to students as they need it.

4. Reward and punishment in every meeting

Reward for the student who was the most active and speak in English only became 'The Best Student'. In this part, all the students attending at the meeting stored one thousand rupiahs at the end of the class then gave them to 'The Best Student'.

Punishment for the student who spoke in Bahasa or said words not in English became 'The Worst Student'. He/she had to tell his/her experiences or sang a song in English in front of class at the end of class.

5. The student who didn't know how to say words in English wrote the words on the whiteboard and asked the teacher how to say it in English.

\section{Students' feedback on the teacher's strategy}

The researcher got students' feedback from face-to-face interview and phone interview. There were 15 students involved in this interview. Here is some information from them:

1. The rule 'Don't speak in Bahasa'. They agreed with it at the first meeting together with reward and punishment. There was also a privilege for anyone who got reward more than once that was 'free from final test'.

2. They worried at the first meeting because they had to speak English only, they were afraid of making mistake in structure or mispronouncing, and they were 
shy to speak in front of the class. At last, they found themselves enjoyed the class. Though, few students felt boring.

3. They felt relax to have activity in pair and in group. Because they had more time to interact with their friends and to express their ideas.

4. They suggested the teacher to apply varied techniques in order to more motivate them. However, they were satisfied with the teacher's strategies in speaking 1 and wished they could meet with the teacher in next speaking class.

\section{DISCUSSION}

The researcher's field note showed that the teacher applied 'Don's speak in Bahasa' as a rule to maintain the flow of the students' interaction in English. That rule led her students to force themselves and herself to speak in English only. As Pollard (2008: 6) suggested that teachers should try to use English as much as possible with their students. When a teacher teaches students at intermediate level and above, all teaching can be done in English. There should really be no need to use the students' mother tongue at these levels. Explanations for activities and definitions of words can be given in English. Similarly, Swain (1985) said that we learn to speak by speaking and that goes for teachers as well as students. The more you practice the more you will improve your own oral skills as well as help your students improve theirs. And, it is not worry if you are not completely fluent or don't have that elusive native accent.

Moreover, the reward and punishment were applied to motivate the students to use the target language as frequently as possible. The reward was as praise for students' effort and punishment was as a consequence for breaking the rule. According to Harmer (1998: 133) pay fine if the students use the mother tongue in speaking activities, is an art of persuading students to use English, above all, it depends on the guidelines that were set, the agreement we made with students, and friendly encouragement and persuasion we use while activities are taking place.

In handling her class, she always gave handouts and put the students either in pair or in group in every meeting. Those activities are two of the most important features of communicative language teaching (CLT) by which students can learn from each other. Thomson (1996) suggested that with pair and group work, students 
can produce a greater amount of language output than they would produce in teacher-centered activities. Students' motivational level is likely to increase. They have the opportunity to develop fluency without any pressure coming from their teacher. Activities requiring pair and group work give learners a safe opportunity to test ideas before actually speaking out in public and lead to the presentation of more highly developed ideas. In addition, such activities help learners complement each other in term of knowledge and skills, which result in greater success in the framework of task-based process. Students' sociolinguistic competence is also improved as these activities enable learners to negotiate meaning and to solve problems in various socially demanding situations.

\section{CONCLUSION AND SUGGESTION}

\section{Conclusion}

Doing direct observation in a big speaking class, the researcher came to conclusion:

1. The teacher encouraged her students to be used to speaking in English from a small environment that was in their classroom in order to build up their confidence. By creating a rule at the first meeting and negotiating it with students made their students were fully aware to speak in English only.

2. The reward and punishment effectively worked in her class to motivate the students.

3. The teacher tried to reach all students by walking around the classroom during pair and group work activities. Thought, it was not easy for her because she handled a big class.

In brief, observation showed that the teacher's endeavor in the speaking class implied strategies to maintain the students' English interaction.

\section{Suggestions}

Making sure the type of speaking activities which is used really capture students' interest and create a real need for communication is very important. And, it also important to give the students all tools and language they need to be able to complete task. A good teacher should always consider using various speaking 
activities, such as; information gap, discussion, debates, spontaneous conversation, role play, problem solving, topic prompt, simulation, etc.

\section{REFERENCE}

Abassi, Malik Abdul, 2011. A Survey of Teaching Strategies in ESL Classroom, (Online), (www.languageinindia.com. Retrieved on January 7 2012)

Atmowardoyo, Haryanto. 2008. Metode Penelitian Kualitatif: Teori Dasar. Makassar: Badan Penerbit Universitas Negeri Makassar.

Brown, H.D. 2007. Teaching by principles: An Interactive approach to language pedagogy ( $3^{\text {rd }}$ Edition). Englewood Cliff, New Jersey: Prentice Hall Regent. White Plains, New York: Longman

Gay, L.R, et al. 2006. Educational Research: Competencies for Analysis and Application Eighth Edition. New Jersey: Person Education, Inc.

Harmers, John. 1998. The Practice of English Language Teaching. London: Longman

Harmer, Jeremy. 2008. The Practice of English Language Teaching (4 ${ }^{\text {th }}$ Edition). Britain: Person Education, Inc.

Ibadurrahman, Ihsan. 2011. Using Norms of Behavior to Regulate an English Only Speaking Class, (Online), (http://www.slideshare.net/, Retrieved on January 23 2012)

Pollard, Lucy. 2008. Guide to Teaching English: A Book to Help You through Your First Two Years in Teaching. Copyright (C) Lucy Pollard 2008 All Rights Reserved.

Richards, C. Jack. 1990. Conversationally speaking: approaches to the teaching of conversation. In Jack C Richards. The Language Teaching Matrix. New York: Cambridge University Press. 67-85

Richard, C. Jack. And Rodgers, S. Theodore. 1995. Approaches and Methods in Language Teaching. Cambridge University Press. USA

Savignon, S. J. 1983. Communicative competence: Theory and classroom practice. ing, MA: Addison-Wesley.

Spratt, Mary. Pulverness, Alan. And Williams, Melanie. 2005. The TKT Course: Teaching Knowledge Test. Cambridge University Press. UK. 
Thompson, G. (1996). Some Misconceptions about Communicative Language Teaching. English Language Teaching Journal. 50/1. 1996

Ur, Penny. (1996). a Course in Language Teaching: Practice \& Theory. Cambridge University Press. 